\title{
FAKTOR-FAKTOR YANG MEMPENGARUHI NILAI TUKAR PETANI SUBSEKTOR HORTIKULTURA DI INDONESIA TAHUN 2014-2018
}

\section{FACTORS THAT AFFECT THE HORTICULTURAL SUBSECTOR FARMERS' TERM OF TRADE IN INDONESIA IN 2014-2018}

\author{
Shelly Oktaviani ${ }^{1}$, Betty Rofatin ${ }^{2}$, Hendar Nuryaman ${ }^{3 *}$ \\ 1) Jurusan Agribisnis, Fakultas Pertanian, Universitas Siliwangi, Jl. Siliwangi No. 24 Tasikmalaya \\ ${ }^{2,3)}$ Dosen Fakultas Pertanian, Universitas Siliwangi, JI. Siliwangi No. 24 Tasikmalaya \\ *E-mail corresponding: hendarnuryaman@unsil.ac.id
}

\begin{abstract}
ABSTRAK
Penelitian ini bertujuan untuk menganalisis faktor-faktor yang mempengaruhi nilai tukar petani subsektor hortikultura di Indonesia tahun 2014-2018. Metode penelitian menggunakan studi literatur dengan data yang digunakan berupa data sekunder. Penelitian ini dilaksanakan dari bulan November 2020 sampai dengan April 2021. Analisis deskriptif digunakan untuk melihat perkembangan nilai tukar petani dan analisis data panel untuk menganalisis faktor-faktor yang mempengaruhi nilai tukar petani subsektor hortikultura di Indonesia tahun 2014-2018. Hasil penelitian menunjukkan bahwa perkembangan nilai tukar petani subsektor hortikultura di Indonesia tahun 2014- 2018 cenderung fluktuatif bahkan mengalami penurunan. Faktor produktivitas cabai, produktivitas jeruk, harga produsen cabai, harga produsen bawang merah dan indeks harga konsumen berpengaruh siginifikan terhadap nilai tukar petani subsektor hortikultura di Indonesia tahun 2014-2018. Sedangkan factor produktivitas bawang merah dan harga produsen jeruk tidak berpengaruh signifikan terhadap nilai tukar petani subsektor hortikultura di Indonesia tahun 2014-2018.
\end{abstract}

Kata kunci: faktor-faktor, nilai tukar petani, hortikultura, analisis data panel.

\section{ABSTRACT}

This study aims to analyze factors that affect the exchange rate of horticulture subsector farmers in Indonesia in 2014-2018. The research method uses literature studies with data used in the form of secondary data. This research was conducted from November 2020 to April 2021. Descriptive analysis was used to see the development of farmer exchange rates and panel data analysis to analyze the factors that influence the horticulture subsector farmer exchange rates in Indonesia in 2014-2018. The results showed that the development of the horticultural subsector farmer exchange rate in Indonesia in 2014-2018 tended to fluctuate and even decreased. The chili productivity factor, citrus productivity, chili producer price, shallot producer price and consumer price index have a significant effect on the horticulture subsector farmer exchange rate in Indonesia in 2014-2018. Meanwhile, onion productivity factors and citrus producer prices do not have a significant effect on the exchange rate of horticultural sub-sector farmers in Indonesia in 2014-2018.

Keywords: factors, farmer exchange rates, horticulture, panel data analysis.

\section{PENDAHULUAN}

Sektor pertanian merupakan sektor yang memiliki peranan penting dalam pembangunan perekonomian. Peran sektor pertanian dalam pembangunan dikelompokkan menjadi tiga kegiatan pokok antara lain menyumbang PDB

Nasional, sumber penerimaan hasil 


\section{FAKTOR-FAKTOR YANG MEMPENGARUHI NILAI TUKAR PETANI SUBSEKTOR HORTIKULTURA DI INDONESIA TAHUN 2014-2018 \\ Shelly Oktaviani, Betty Rofatin, Hendar Nuryaman}

ekspor serta penyediaan lapangan kerja sehingga dapat memperbaiki pendapatan masyarakat. Salahsatu subsektor pertanian yang memiliki peranan strategis dalam memajukan perekonomian Indonesia adalah subsektor tanaman hortikultura. Pembangunan pada subsektor hortikultura menunjukkan hasil yang baik pada pembentukan Produk Domestik Bruto (PDB). Nilai PDB subsektor hortikultura tahun 2014-2018 terus meningkat serta memiliki rata-rata laju pertumbuhan tertinggi kedua setelah subsektor peternakan (BPS, 2020).

Komoditas hortikultura merupakan komoditas potensial yang mempunyai nilai ekonomi dan permintaan pasar yang tinggi. Sesuai SK Menteri Pertanian Nomor: 511/Kpts/PD310/9/2006, komoditas binaan Direktorat Jenderal Hortikultura mencakup 323 jenis komoditas yang terdiri dari 60 jenis buahbuahan, 80 jenis komoditas sayuran, 66 jenis komoditas tanaman obat dan 117 jenis komoditas florikultura.

Penetapan komoditas unggulan didasarkan pada kriteria sebagai berikut: 1) berdampak terhadap ekonomi makro, 2) produksi, 3) luas area, 4) potensi ekspor, 5) substitusi impor, 6) jumlah pelaku usaha, 7) nilai ekonomi, 8) potensi nilai tambah, 9) ketersediaan teknologi, 10) kebutuhan bahan baku industri, 11) permintaan domestik, 12) pangsa pasar relatif dalam kelompok komoditas.
Berdasarkan hal tersebut, perlu penetapan dan pengembangan komoditas prioritas hortikultura nasional. Terkait dengan penetapan komoditas unggulan hortikultura maka telah diterbitkan Permentan No. 76/Permentan/OT.140/12/2012 tentang Syarat dan Tatacara Penetapan Produk Unggulan Hortikultura dan mengacu pada Peraturan Menteri Pertanian No.50/Permentan/OT.140/8/2012 tentang Pedoman Pengembangan Kawasan Pertanian dan Peraturan Menteri Pertanian No.45/Kpts/PD.200/1/2015 tentang Penetapan Kawasan Cabai, Bawang Merah, dan Jeruk Nasional. Adapun komoditas hortikultura yang akan secara intensif mendapat perhatian utama pada level nasional pada periode 2015-2019 adalah: aneka cabai, bawang merah, jeruk. Provinsi yang memiliki luas panen komoditas unggulan hortikultura terbesar yaitu Sumatera Utara, Sumatera Barat, Jawa Barat, Jawa Tengah, Jawa Timur, Nusa Tenggara Barat dan Sulawesi Selatan

Pembangunan pada subsektor hortikultura tidak terlepas dari adanya kebijakan pemerintah. Pada RPJMN 2015-2019, NAWA CITA menjadi agenda prioritas Kabinet Kerja dengan mengarahkan pembangunan pertanian ke depan untuk mewujudkan kedaulatan pangan, agar Indonesia sebagai bangsa dapat mengatur dan memenuhi 
kebutuhan pangan rakyatnya secara berdaulat. Kedaulatan pangan diterjemahkan dalam bentuk kemampuan bangsa dalam hal: (1) mencukupi kebutuhan pangan dari produksi dalam negeri, (2) mengatur kebijakan pangan secara mandiri, serta (3) melindungi dan mensejahterakan petani sebagai pelaku utama usaha pertanian pangan sehingga Kementerian Pertanian hadir dengan visi: "Terwujudnya Kedaulatan Pangan dan Kesejahteraan Petani".

Salah satu visi Kementerian Pertanian adalah kesejahteraan petani. Menurut Sadikin dan Subagyono (2009) terdapat beberapa variabel yang mempengaruhi kesejahteraan petani diantaranya yaitu Nilai Tukar Petani (NTP). Perhitungan NTP diperoleh dari perbandingan indeks harga yang diterima petani terhadap indeks harga yang dibayar petani. Nilai tukar petani menggambarkan tingkat daya tukar atau daya beli petani terhadap produk yang dibeli atau dibayar petani yang mencakup konsumsi dan input produksi yang dibeli. Semakin tinggi NTP, semakin baik daya beli petani terhadap produk konsumsi dan input produksi tersebut, dan berarti secara relatif lebih sejahtera.

Simatupang dan Maulana (2008) mengemukakan bahwa penanda kesejahteraan yang unik bagi rumah tangga tani praktis tidak ada, sehingga NTP menjadi pilihan satu-satunya bagi pengamat pembangunan pertanian dalam menilai tingkat kesejahteraan petani. Dengan demikian, NTP merupakan salah satu indikator relatif tingkat kesejahteraan petani. Semakin tinggi NTP, relatif semakin sejahtera tingkat kehidupan petani.

Pembangunan pada subsektor tanaman hortikultura saat ini belum sepenuhnya memberikan hasil yang maksimal pada NTP tanaman hortikultura. NTP tanaman hortikultura di Indonesia dari tahun 2014-2018 secara berturut turut yaitu 102.55, 101.63, 102.77, 101.75, 101.09. sebagai salah satu indikator kesejahteraan petani menunjukkan nilai indeks yang cenderung menurun dari tahun 20142018, yang mengartikan bahwa kesejahteraan petani tanaman hortikultura cenderung menurun tiap tahunnya.

Menurut Schuh (1976) interaksi antara kebijakan makroekonomi terhadap sektor pertanian adalah melalui pengaruhnya pada inflasi, nilai tukar riil, suku bunga riil, dan insentif ekspor-impor pertanian. Selain itu faktor yang memiliki pengaruh terhadap kesejahteraan petani adalah penetapan tingkat harga. Harga dalam indikator makroekonomi dapat dilihat tingkat inflasi, yang mana tingkat inflasi dapat dilihat dari dua perspektif. Inflasi dapat dilihat dari sisi konsumen dengan melihat pergerakan indeks harga 


\section{FAKTOR-FAKTOR YANG MEMPENGARUHI NILAI TUKAR PETANI SUBSEKTOR HORTIKULTURA DI INDONESIA TAHUN 2014-2018 \\ Shelly Oktaviani, Betty Rofatin, Hendar Nuryaman}

konsumen, dan dari sisi produsen dapat dilihat dari pergerakan indeks harga produsen.

Tujuan dari dilakukannya penelitian ini adalah untuk mengetahui perkembangan nilai tukar petani subsektor hortikultura di Indonesia tahun 2014-2018 dan mengetahui faktor-faktor yang mempengaruhi nilai tukar petani subsektor hortikultura di Indonesia tahun 2014-2018.

\section{METODE PENELITIAN}

Penelitian dilakukan mulai dari November 2020 hingga April 2021 yang meliputi tujuh provinsi diantaranya Sumatera Utara, Sumatera Barat, Jawa Barat, Jawa Tengah, Jawa Timur, Nusa Tenggara Barat dan Sulawesi Selatan dengan pertimbangan bahwa ketujuh provinsi tersebut merupakan provinsi dengan luas panen penghasil komoditas unggulan hortikultura (cabai, bawang merah, jeruk) terbesar di Indonesia.

Penelitian ini merupakan penelitian yang menggunakan metode studi literatur. Data yang dikumpulkan dalam penelitian ini terdiri dari data sekunder yang diperoleh dari Badan Pusat Statistik (BPS) serta Pusat Data dan Sistem Informasi Pertanian.

Analisis digunakan untuk mengetahui perkembangan nilai tukar petani subsektor hortikultura di Indonesia tahun 2014-2018, kemudian untuk mengetahui faktor-faktor yang mempengaruhi nilai tukar petani subsektor hortikultura di Indonesia tahun 2014-2018 menggunakan analisis data panel. Pengujian secara simultan menggunakan uji $F$, kemudian pengujian secara parsial menggunakan uji t-parsial. Pengujian dilakukan dengan bantuan program E-Views versi 10.

\section{HASIL DAN PEMBAHASAN}

Perkembangan Nilai Tukar Petani Subsektor Hortikultura di Indonesia Tahun 2014-2018

'Perkembangan rata-rata nilai tukar petani subsektor hortikultura di Indonesia menunjukkan kecenderungan menurun periode waktu 2014-2018. Tahun 2014 NTP subsektor hortikultura sebesar 102.07. Nilai tersebut menurun di tahun 2015 sebesar $1.6 \%$ menjadi 100.44 dan kembali meningkat sebesar $0.7 \%$ menjadi 101.14 di tahun 2016. Tahun 2014-2016 petani hortikultura masih mengalami surplus karena data NTP subsektor hortikultura berada di atas nilai 100. Hal tersebut mencerminkan bahwa harga produk komoditas hortikultura masih relatif lebih tinggi dari harga barang konsumsi dan biaya produksinya. Dengan kata lain, pendapatan petani lebih besar dibandingkan pengeluarannya yang menyebabkan nilai tukar petani subsektor hortikultura meningkat. Tingkat kesejahteraan petani pun menjadi lebih baik seiring meningkatnya nilai tukar petani. 
Meningkatnya kesejahteraan petani mencerminkan bahwa rata-rata daya beli petani mengalami peningkatan, dimana petani mampu mencukupi kebutuhan faktor produksi pertanian dan konsumsi rumah tangga sehari-hari dari hasil usaha pertaniannya. Namun, NTP subsektor hortikultura kemudian menurun hingga dibawah angka 100 pada tahun 2017 dan 2018 yaitu sebesar 99.22 dan 98.15. Kondisi tersebut menunjukkan bahwa petani subsektor hortikultura mengalami defisit. Harga produk hortikultura meningkat lebih rendah dari kenaikan harga barang konsumsi dan biaya produksi, sehingga pendapatan petani menurun yang menyebabkan menurunnya nilai tukar petani. Tingkat kesejahteraan petani pun menjadi rendah seiring menurunnya nilai tukar petani.

Menurunnya kesejahteraan petani mencerminkan bahwa rata-rata daya beli petani mengalami penurunan, dimana petani belum mampu mencukupi kebutuhan faktor produksi pertanian dan konsumsi rumah tangga sehari-hari dari hasil usaha pertaniannya. Pencapaian tertinggi dari NTP subsektor hortikultura terjadi pada tahun 2014 yaitu sebesar 102.07. Setelah itu, NTP subsektor hortikultura mencapai titik terendah pada 2018 sebesar 98.15.

Perkembangan Nilai Tukar Petani Subsektor Hortikultura pada Tujuh Provinsi di Indonesia Tahun 2014-2018
Nilai tukar petani subsektor hortikultura pada tujuh provinsi di Indonesia selama lima tahun menunjukkan kecenderungan menurun. Pada tahun 2014, 2015, 2016, 2017 dan 2018 rata-rata NTP secara berturut-turut adalah sebesar 102.07, 100.44, 101.14, 99.22, dan 98.15. Terdapat beberapa provinsi yang memiliki nilai selalu melebihi angka 100 dari tahun 20142018. Artinya petani provinsi tersebut selalu mengalami surplus di tahun 20142018, yaitu provinsi Jawa Barat, Jawa Timur dan Sulawesi Selatan. Pendapatan petani hortikultura di provinsi Jawa Barat, Jawa Timur dan Sulawesi Selatan lebih besar dibandingkan pengeluarannya yang menyebabkan nilai tukar petani subsektor hortikultura meningkat. Tingkat kesejahteraan petani pun menjadi lebih baik seiring meningkatnya nilai tukar petani.

Sebaliknya, terdapat beberapa provinsi yang tidak pernah mengalami surplus atau selalu defisit dari tahun 2014-2018. Provinsi tersebut antara lain Sumatera Utara, Sumatera Barat dan Nusa Tenggara Barat. Hal ini menunjukkan harga produk hortikultura meningkat lebih rendah dari kenaikan harga barang konsumsi dan biaya produksi, sehingga pendapatan petani menurun. Sementara provinsi Jawa Tengah menunjukkan NTP yang fluktuatif namun cenderung menurun dan 


\section{FAKTOR-FAKTOR YANG MEMPENGARUHI NILAI TUKAR PETANI SUBSEKTOR HORTIKULTURA DI INDONESIA TAHUN 2014-2018 \\ Shelly Oktaviani, Betty Rofatin, Hendar Nuryaman}

mengalami surplus hanya di tahun 2014 saja.

Faktor-Faktor yang Mempengaruhi
Nilai Tukar Petani Subsektor Hortikultura di Indonesia Tahun 20142018

Hasil pengujian t-statistik menunjukkan bahwa pada model penelitian ini terdapat lima variabel yang signifikan pada taraf nyata $5 \%$. Variabelvariabel tersebut antara lain produktivitas cabai, produktivitas jeruk, harga produsen cabai, harga produsen bawang merah dan indeks harga konsumen. Sedangkan terdapat dua variabel independen yang tidak signifikan yaitu variabel produktivitas bawang merah dan harga produsen jeruk.

Tabel 1. Estimasi Model Nilai Tukar Petani Hortikultura Pada 7 Provinisi Di Indonesia Tahun 2014-2018

\begin{tabular}{ccccc}
\hline Variable & Coefficient & Std. Error & t-Statistic & Prob. \\
\hline C & 130.8138 & 15.55053 & 8.412174 & 0.0000 \\
X1 & -0.841804 & 0.318922 & -2.639533 & 0.0153 \\
X2 & 0.818457 & 1.200226 & 0.681919 & 0.5027 \\
X3 & -0.218821 & 0.079088 & -2.766814 & 0.0116 \\
X4 & -0.000147 & $6.20 \mathrm{E}-05$ & -2.377838 & 0.0270 \\
X5 & 0.000668 & 0.000160 & 4.185025 & 0.0004 \\
X6 & -0.000349 & 0.000204 & -1.709881 & 0.1020 \\
X7 & -0.207078 & 0.076579 & -2.704118 & 0.0133 \\
\hline
\end{tabular}

\section{Produktivitas Cabai (X1)}

Variabel produktivitas cabai berpengaruh signifikan pada taraf $\alpha=5 \%$ terhadap nilai tukar petani subsektor hortikultura. Hal ini dikarenakan nilai probabilitas (X1) sebesar 0.0153 yang kurang dari dari 0,05 (taraf nyata $\alpha=5 \%$ ). Nilai koefisien dari variabel produktivitas cabai bertanda negatif yaitu sebesar 0.841804 . Hal ini berarti peningkatan produktivitas cabai sebesar 1 ton/hektar akan menurunkan nilai tukar petani subsektor hortikultura sebesar 0.841804 , ceteris paribus.

Pada saat panen raya, pasokan cabai melimpah sehingga terjadi penumpukan cabai dipasaran. Hal ini membuat harga cabai menjadi lebih murah, cabai yang tidak terjual akan menjadi rusak atau membusuk dipasaran karena cabai merupakan salahsatu produk hortikultura yang mudah rusak setelah panen. Hal ini akan membuat petani maupun pedagang mengalami kerugian yang sangat besar. Cabai termasuk sayuran yang mudah rusak akibat respirasi, perubahan kimia serta penampakan fisik berupa pelayuan, pengeringan ataupun pembengkakan yang berair kemudian diikuti pembusukan (Kader, 1992). Maka kaitannya antara produktivitas cabai dengan nilai tukar petani hortikultura bisa dikatakan bahwa semakin tinggi produktivitas cabai maka terjadi penumpukan cabai dipasaran dan membuat petani mengalami kerugian 
yang mencerminkan indeks harga yang diterima petani menurun.

\section{Produktivitas Bawang Merah (X2)}

Hasil analisis menujukkan produktivitas bawang merah tidak berpengaruh signifikan terhadap nilai tukar petani subsektor hortikultura. Hal tersebut dikarenakan nilai probabilitas variabel menunjukkan lebih besar dari taraf nyata yang digunakan (0.05) yaitu sebesar 0.5027. Nilai koefisien dari variabel produktivitas bawang merah bertanda positif yaitu sebesar 0.818457 .

Produktivitas bawang merah pada tujuh provinsi yang dianalisis memiliki produktivitas di atas rata-rata nasional. Provinsi yang cenderung memiliki produktivitas bawang merah selalu di bawah rata-rata produktivitas nasional yaitu provinsi Sumatera Utara dan Jawa Timur. Meskipun demikian, harga produsen bawang merah di Provinsi Jawa Timur memiliki nilai yang cukup besar. Bahkan, pada tahun 2017 merupakan harga paling tinggi yang diterima petani dibandingkan dengan provinsi lainnya selama periode 2014-2018. Sehingga meskipun produktivitas bawang merah rendah, akan tetapi nilai tukar petani yang diperoleh selalu melebihi angka 100 dan dapat dikatakan sejahtera.

Besarnya produktivitas bawang merah pada tujuh provinsi yang dinalisis tidak diikuti dengan besarnya harga yang diterima petani. Berdasarkan data dari
Pusat Data dan Sistem Informasi Pertanian (2019), rata-rata harga produsen bawang merah nasional adalah Rp 19.724. Hal ini menunjukkan bahwa harga yang diterima petani cenderung berada dibawah rata-rata harga produsen bawang merah nasional sehingga besarnya produktivitas bawang merah tidak berpengaruh langsung terhadap nilai tukar petani subsektor hortikultura.

\section{Produktivitas Jeruk (X3)}

Hasil analisis menujukkan produktivitas jeruk berpengaruh signifikan terhadap nilai tukar petani subsektor hortikultura. Hal ini dikarenakan nilai probabilitasnya sebesar 0.0116 yang kurang dari dari 0,05 (taraf nyata $\alpha=5 \%$ ). Nilai koefisien dari produktivitas cabai bertanda negative sebesar -0.218821 . Hal ini berarti peningkatan produktivitas cabai sebesar 1 ton/hektar akan menurunkan nilai tukar petani hortikultura sebesar 0.218821 , ceteris paribus.

Nilai koefisien yang bertanda negative dikarenakan meskipun produktivitas jeruk tinggi, akan tetapi jeruk yang dihasilkan belum mampu memenuhi permintaan konsumen menengah ke atas yang terus meningkat daya belinya, dan menghendaki buah jeruk berkualitas prima (Badan Penelitian dan Pengembangan, 2014).

\section{Harga Produsen Cabai (X4)}

Hasil analisis menunjukkan harga produsen cabai (X4) berpengaruh 


\section{FAKTOR-FAKTOR YANG MEMPENGARUHI NILAI TUKAR PETANI SUBSEKTOR HORTIKULTURA DI INDONESIA TAHUN 2014-2018 \\ Shelly Oktaviani, Betty Rofatin, Hendar Nuryaman}

signifikan terhadap nilai tukar petani subsektor hortikultura. Hal tersebut dikarenakan nilai probabilitasnya kurang dari taraf nyata yang digunakan $(0.0270<$ 0.05). Nilai koefisien dari variabel harga produsen cabai bertanda negatif yaitu sebesar -0.000147 . Hal ini berarti peningkatan harga produsen cabai sebesar $1 \mathrm{Rp} / \mathrm{kg}$ akan menurunkan nilai tukar petani hortikultura sebesar 0.000147 , ceteris paribus. Hal ini sejalan dengan penelitian Pratama dan Yasa (2018) bahwa elastisitas harga cabai terhadap permintaan cabai yaitu -0.010 yang berarti meningkatnya harga cabai sebesar 1 persen maka akan menurunkan jumlah permintaan cabai sebesar 0.010 persen.

Kaitannya antara harga produsen cabai dengan nilai tukar petani subsektor hortikultura bisa dikatakan bahwa semakin tinggi harga produsen cabai, maka permintaan terhadap cabai pun menjadi menurun yang mencerminkan indeks harga yang diterima petani menjadi relatif lebih rendah dan berdampak langsung terhadap penurunan NTPH.

\section{Harga Produsen Bawang Merah} (X5)

Variabel harga produsen bawang merah berpengaruh nyata pada taraf $\alpha=$ $5 \%$ terhadap nilai tukar petani hortikultura. Hal ini dikarenakan nilai probabilitasnya sebesar 0.0004 yang lebih kecil dari 0,05 (taraf nyata $\alpha=5 \%$ ). Nilai koefisien dari variabel harga produsen bawang merah bertanda positif yaitu sebesar 0.000668. Hal ini berarti peningkatan sebesar $1 \mathrm{Rp} / \mathrm{kg}$ harga produsen bawang merah akan meningkatkan nilai tukar petani subsektor hortikultura sebesar 0.000668 , ceteris paribus. Peningkatan harga atau nilai tukar suatu komoditi pertanian mencerminkan indeks harga yang diterima petani menjadi relatif lebih tinggi dan berdampak langsung terhadap peningkatan NTPH.

\section{Harga Produsen Jeruk (X6)}

Variabel harga produsen jeruk tidak berpengaruh nyata pada taraf $\alpha=$ $5 \%$ terhadap nilai tukar petani hortikultura. Hal ini dikarenakan nilai probabilitasnya sebesar 0.1020 yang lebih besar dari 0,05 (taraf nyata $\alpha=5 \%$ ). Hal ini dikarenakan lemahnya kelembagaan petani dalam meningkatkan posisi tawar petani produsen jeruk dimana kalah bersaing dengan produkproduk impor.

\section{Indeks Harga Konsumen (X7)}

Variabel indeks harga konsumen berpengaruh signifikan terhadap nilai tukar petani subsektor hortikultura pada taraf nyata $5 \%$. Hal ini dikarenakan nilai probabilitasnya sebesar $0.0133<0,05$ (taraf nyata $\alpha=5 \%$ ). Koefisien indeks harga konsumen bertanda negative yaitu -0.207078. Hal ini berarti setiap 
peningkatan sebesar 1 indeks harga konsumen akan menurunkan nilai tukar petani subsektor hortikultura sebesar 0.207078 , ceteris paribus. Indeks harga konsumen dapat mencerminkan tingkat inflasi di pedesaan, baik kelompok bahan makanan maupun kelompok harga lainnya.

Indeks harga konsumen yang digunakan dalam penelitian ini yaitu IHK secara umum. Perkembangan hargaharga barang dan jasa yang beredar di pasar dapat dilihat melalui indikator Indeks Harga Konsumen (IHK). Berdasarkan hasil regresi IHK total, Indonesia menunjukkan pengaruh yang negatif terhadap nilai tukar petani hortikultura, yaitu apabila perekonomian berada pada tingkat inflasi yang tinggi justru akan menurunkan kesejahteraan petani, hal ini disebabkan karena ketika inflasi tinggi maka harga-harga pada faktor-faktor produksi pertanian juga barang konsumsi rumah tangga semakin mahal. Semakin tingginya IHK mencerminkan biaya yang dikeluarkan petani menjadi relatif lebih tinggi.

Hal ini sejalan dengan penelitian Bafadal (2014) bahwa inflasi memberi pengaruh negatif secara nyata terhadap nilai tukar petani. Pengaruh inflasi terhadap nilai tukar petani bersifat responsif, dimana inflasi sebesar $1 \%$ dapat menurunkan nilai tukar petani sebesar $1.6 \%$.

\section{KESIMPULAN}

1. Rata-rata nilai tukar petani subsektor hortikultura di Indonesia menunjukkan kecenderungan menurun pada tahun 2014-2018. Rata-rata nilai tukar petani subsektor hortikultura di Indonesia tahun 20142018 secara berturut-turut yaitu 102.07, 100.44, 101.14, 99.22 dan 98.15 .

2. Produktivitas cabai, produktivitas jeruk, harga produsen cabai, harga produsen bawang merah dan indeks harga konsumen berpengaruh siginifikan terhadap nilai tukar petani subsektor hortikultura. Sedangkan produktivitas bawang merah dan harga produsen jeruk tidak berpengaruh signifikan terhadap nilai tukar petani subsektor hortikultura di Indonesia tahun 2014-2018.

\section{DAFTAR PUSTAKA}

Badan Penelitian dan Pengembangan Pertanian. 2014. Teknologi Perbaikan Produktivitas dan Mutu Buah Jeruk untuk Menghadapi Jeruk Impor. Badan Penelitian dan Pengembangan Pertanian Kementerian Pertanian.

Badan Pusat Statistik. 2018. Statistika Nilai Tukar Petani 2014-8. Badan Pusat Statistik Indonesia. Jakarta.

Badan Pusat Statistik. 2020. Harga Produsen. Badan Pusat Statistik Indonesia. Jakarta.

Badan Pusat Statistik. 2020. Indeks Harga Konsumen dan Inflasi 


\section{FAKTOR-FAKTOR YANG MEMPENGARUHI NILAI TUKAR PETANI SUBSEKTOR HORTIKULTURA DI INDONESIA TAHUN 2014-2018 \\ Shelly Oktaviani, Betty Rofatin, Hendar Nuryaman}

Bulanan Indonesia. Badan Pusat Statistik Indonesia. Jakarta.

Badan Pusat Statistik. 2020. [Seri 2010] Laju Pertumbuhan PDB Seri 2010, 2011-2020. Badan Pusat Statistik Indonesia. Jakarta.

Bafadal, Azhar. 2014. Pengaruh Kinerja Ekonomi Makro Terhadap Nilai Tukar Petani. QE Journal Jurusan Agribisnis Fakultas Pertanian Universitas Halu Oleo. Vol. 03 No. 03 : 162-178.

Direktorat Jenderal Hortikultura. 2016. Rencana Strategis Direktorat Jenderal Hortikultura Kementerian Pertanian 2015-2019. Direktorat Jenderal Hortikultura Kementerian Pertanian. Indonesia.

Fajri, M.R., S. Marwanti dan W. Rahayu. 2016. Analisis Faktor-Faktor yang Mempengaruhi Nilai Tukar Petani Sebagai Indikator Kesejahteran Petani Padi di Kabupaten Sragen. Jurnal AGRISTA Fakultas Pertanian Universitas Sebelas Maret. Vol. 4 No. 2 : 85-94.

Kader, A.A. 1992. Postharvest Technology of Horticultural Crops.
The Regents of The University of The California. USA

Pratama, I.G.R. dan I.G.W.M. Yasa. 2018. Elastisitas Harga Cabai dan Pendapatan Pedagang Kaki Lima di Kota Denpasar. E-Jurnal Ekonomi Pembangunan Universitas Udayana. Vol. 07 No. 9 : 162-178

Pusat Data dan Informasi Pertanian. 2019. Statistik Harga Komoditas Pertanian. Pusat Data dan Informasi Pertanian Sekretariat Jenderal - Kementerian Pertanian. Indonesia.

Sadikin I, Subagyono K. 2009. Kinerja Beberapa Indikator Kesejahteraan Petani Padi di Perdesaan Kabupaten Karawang. Balai Pengkajian Teknologi Pertanian.

Schuh GE. 1976. The New Macroeconomic of Agriculture. American Journal of Agricultural Economics Vol 58 (5) : 802 - 811.

Simatupang, P. dan M. Maulana. 2008. Kaji Ulang Konsep dan Perkembangan Nilai Tukar Petani Tahun 2003-2006. Jurnal Ekonomi dan Pembangunan, LIPI. 